Binghamton University

The Open Repository @ Binghamton (The ORB)

2012

\title{
The Problem of Debt-for-Nature Swaps from a Human Rights Perspective
}

Nicole Hassoun

Binghamton University--SUNY, nhassoun@binghamton.edu

Follow this and additional works at: https://orb.binghamton.edu/philosophy_fac

Part of the Philosophy Commons

\section{Recommended Citation}

Hassoun, Nicole, "The Problem of Debt-for-Nature Swaps from a Human Rights Perspective" (2012).

Philosophy Faculty Scholarship. 15.

https://orb.binghamton.edu/philosophy_fac/15

This Article is brought to you for free and open access by the Philosophy at The Open Repository @ Binghamton (The ORB). It has been accepted for inclusion in Philosophy Faculty Scholarship by an authorized administrator of The Open Repository @ Binghamton (The ORB). For more information, please contact ORB@binghamton.edu. 


\section{Carnegie Mellon University \\ Research Showcase@CMU}

Department of Philosophy

Dietrich College of Humanities and Social Sciences

2010

\section{Are Debt for Climate Swaps Morally Permissible?}

Nicole Hassoun

Carnegie Mellon University

Matt Frank

Follow this and additional works at: http://repository.cmu.edu/philosophy

Part of the Philosophy Commons

This Working Paper is brought to you for free and open access by the Dietrich College of Humanities and Social Sciences at Research Showcase@ CMU. It has been accepted for inclusion in Department of Philosophy by an authorized administrator of Research Showcase @ CMU. For more information, please contact research-showcase@andrew.cmu.edu. 


\section{Are DebT-FOR-Climate SWAPS Morally Permissible? ${ }^{i}$}

\section{INTRODUCTION}

Environmental degradation is a problem as immense in scope as it is horrific in detail. Climate change, in particular, threatens many species and ecosystems. ${ }^{\text {ii }}$ Failing to mitigate climate change risks inter alia stronger hurricanes, massive droughts, loss of biodiversity, the spread of disease, and the long-term flooding of coastal areas around the world. ${ }^{\mathrm{iii}}$ Another problem as immense and horrific as environmental degradation is extreme poverty. Over 1 billion people are living in extreme poverty, unable to secure adequate food, shelter, clothing, healthcare, clean water and sanitation. ${ }^{\text {iv }}$ Eighteen million people die every year from such poverty-related causes as malaria, AIDS, and starvation. ${ }^{\mathrm{v}}$ Debt-for-climate swaps might help to solve both problems.

Debt-for-climate swaps (and, more generally, debt-for-nature swaps) are agreements between creditors - either developed countries or international financial institutions - and developing country debtors. In bilateral swaps, a creditor agrees to forgive a developing country's debt on the condition that the developing country fund and implement a domestic environmental program (e.g., to preserve forests). Generally, non-governmental conservation organizations such as the World Wildlife Fund or Conservation International broker these bilateral swaps. Sometimes, however, debt-for-climate swaps are three-party agreements between a creditor, a non-governmental conservation organization, and a developing country debtor. In commercial swaps, creditors sell a developing country's debt to a conservation organization at a reduced rate. Then the conservation organization agrees to forgive part or all of the debt so long as the developing country funds and implements a domestic conservation program. ${ }^{\mathrm{vi}}$ Dozens of countries have participated in debt-for-climate (and other debt-for-nature) swaps. ${ }^{\text {vii }}$

Environmentalists praise such swaps for their potential to mitigate environmental

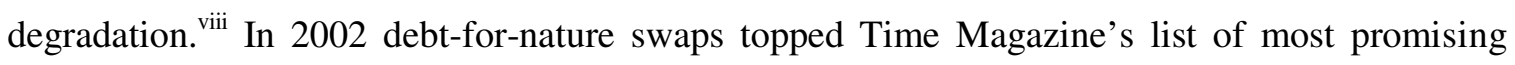
conservation strategies and the recent climate crisis has added impetus to the move towards debt- 
for-climate swaps. ${ }^{\text {ix }}$ Such swaps have already helped create large nature preserves. In 1987, for instance, Conservation International brokered a swap that created Bolivia's Beni Biosphere Reserve. ${ }^{\mathrm{x}}$ In 2007, Peru agreed to protect ' 7.5 million acres of tropical rain forest containing pink river dolphins, jaguars, scarlet macaws and giant water lilies. ${ }^{\mathrm{xi}}$ And more recently, in 2009, Conservation International brokered a swap that will purportedly preserve Sumatra's forests and protect its many endangered species. ${ }^{\text {xii }}$

Others praise debt-for-climate (and nature) swaps for their potential to alleviate extreme poverty. ${ }^{\text {xii }}$ Developing countries often face crushing international debt burdens, which can interfere with their ability to eliminate - or, at least, alleviate - extreme poverty within their borders. ${ }^{\text {xiv }}$ Because debt-for-climate swaps reduce the amount of money developing countries must spend servicing their debts, such swaps may help these countries lift their people out of extreme poverty. ${ }^{\mathrm{xv}}$ At first blush, then, debt-for-climate swaps seem to provide win-win solutions to the problems of environmental degradation and extreme poverty. As such, one might naturally assume that debt-for-climate swaps are morally permissible, if not morally obligatory.

This paper will argue that, appearances not withstanding, debt-for-climate swaps may sometimes be morally questionable, if not impermissible. The upshot of the paper is threefold: first, it is unwise to assume without scrutiny that any particular debt-for-climate swap is morally permissible; second, and more generally, it is important to exercise some degree of moral imagination when reflecting on the permissibility of actions for which there are allegedly no better alternatives; third, it may turn out that national and international policies, rules, and institutions must change in order to make many seemingly innocuous or even good policies or actions like debt-for-climate swaps permissible.

Our argument is motivated by an analogy between international loans and debt-forclimate swaps. In particular, the argument draws on structural similarities between the economic conditions traditionally placed on international loans to developing countries (economic conditionality) and the environmental conditions placed on debt-for-climate swaps 
(environmental conditionality). So, after setting out the moral framework we use to evaluate the permissibility of debt-for-climate swaps, we will discuss some moral problems that have been attributed to economic conditionality. We will then show how similar problems may apply to debt-for-climate swaps both in theory and in practice. Finally, we will entertain some objections to our argument.

Inquiry into the permissibility of debt-for-climate swaps is important in the context of debates about how we should mitigate climate change. Consider that, as a result of its Tropical Forest Conservation Act, the U.S. signed twelve debt-for-nature agreements with countries including Panama, Bangladesh, Botswana, Belize, Costa Rica, Colombia, El Salvador, Guatemala, Jamaica, Panama, Paraguay, Peru, and the Philippines. ${ }^{\text {xvi }}$ By 2006, the U.S. had already saved a million acres of forest with such swaps. ${ }^{x v i i}$ If we use what seems to be a conservative estimate of .5 metric tons of carbon saved per acre, then these swaps have saved around 500,000 metric tons of carbon from entering the atmosphere per year. (For a frame of reference, global emissions are about 7 billion tons per year.) ${ }^{\text {xviii }}$ Furthermore, as some developing countries have proposed that they be allowed to sell their carbon credits in exchange for debt relief, it seems that debt-for-climate swaps hold great potential for dealing with global climate change, whether used in lieu of, or in addition to, traditional carbon trading programs. ${ }^{\text {xix }}$ Although many discuss the permissibility of different carbon-trading regimes, we know of few papers examining the permissibility of debt-for-climate swaps.

\section{HUMAN RIGHTS AND EXTREME POVERTY}

This paper will work within a human rights framework, which assumes that we all possess human rights in virtue of our humanity and that we all have an equal claim to their fulfillment. ${ }^{\mathrm{xx}}$ Human rights have traditionally been understood as the rights necessary to secure individuals' basic interests and/or autonomy. ${ }^{\mathrm{xxi}}$ To stay neutral between these competing accounts of human rights, however, this paper will simply say that people have a human right to the things they need to secure a minimally decent life (so that whatever interests or autonomy individuals 
must be able to secure are included here). ${ }^{\text {xii }}$ We have human rights to those things that are necessary for living a minimally decent life and against those things that are detrimental to living a minimally decent life. ${ }^{\text {xxiii }}$

On this framework, we have a human right against extreme poverty—or, alternatively, a human right to what we need in order to avoid extreme poverty. For extreme poverty poses a common threat to individuals' ability to live minimally decent lives. It is worth noting how uncontroversial this assumption is. Whatever a minimally decent life requires, surely it requires at least those things essential for sustaining life itself, and these are ex hypothesi the very things put at risk by extreme poverty.

Now supposing that everyone has a human right against extreme poverty, it is incumbent on us (i.e., humanity) to ameliorate it. But just what does it mean to lay responsibility for securing the human rights of everyone at the doorstep of humanity? What does it mean to say the duties that arise from human rights are duties of humanity? Here, we might follow James Nickel who provides a clear and plausible answer:

(1) governments are the primary addressees of the human rights of their residents, with duties both to respect and to uphold their human rights; (2) governments have negative duties to respect the rights of people from other countries; (3) individuals have negative responsibilities to respect the human rights of people at home and abroad; (4) individuals have responsibilities as voters and citizens to promote human rights in their own country; and (5) governments, international organizations and individuals have back-up responsibilities for the fulfillment of human rights around the world. ${ }^{\text {xiv }}$

It is helpful to separate the negative duties from the positive duties that arise from human rights. On the one hand, negative duties that arise from human rights are addressed to all of humanity all of the time: each of us, along with our governments, and non-governmental organizations, has a duty to avoid taking actions, implementing policies, and supporting 
institutions that help undermine human rights anywhere at anytime. ${ }^{\mathrm{xxv}}$ It is, for instance, always incumbent on both Kenyans and U.S. citizens, along with the Kenyan government and the United States government, and (say) the World Bank and the World Wildlife Fund, to avoid taking actions, implementing policies, and supporting institutions that undermine the human rights of either Kenyans or Americans in this way (henceforth simply undermine). On the other hand, positive duties that arise from human rights are not addressed to all of humanity. Rather, they begin as domestic duties and, if necessary, become international duties. ${ }^{\text {xxi }}$ It is, for instance, the primary duty of the Kenyan government - not (say) the United States government, the World Bank, or the World Wildlife Fund - to take actions, implement policies, and support institutions that secure the human rights of Kenyans. Similarly, it is the primary duty of the United States government - not (say) the Kenyan government, the World Bank, or the World Wildlife Fund to take actions, implement policies, and support institutions that secure the human rights of U.S. citizens. When a country is unable to secure the human rights of its people, however, it becomes a secondary (positive) duty of the international community - requiring not just states but individuals and non-governmental organizations - to assist. So, for instance, if the Kenyan government is unable to secure the human rights of its people, and if the United States government has already fulfilled its primary duty to secure the human rights of its people, then, other things being equal, it is the responsibility of the United States government - along with similarly capable members of the international community - to assist in securing the human rights of Kenyans. ${ }^{\text {xxvii }}$

There is even some basis for this interpretation of the duties correlative to human rights in international law. Consider, for instance, Article 2(1) of the international covenant on economic and social rights, part of the UN declaration of human rights as explicated in the general comments. ${ }^{\text {xxviii }}$ It says that to fulfill rights:

Each State Party to the present Covenant ...[must undertake]... steps, individually and through international assistance and cooperation, especially economic and 
technical, to the maximum of its available resources, with a view to achieving progressively the full realization of the rights recognized in the present Covenant by all appropriate means, including particularly the adoption of legislative measures.

The third general comment states:

The Committee notes that the phrase [in Article 2(1)] 'to the maximum of its available resources' was intended by the drafters of the Covenant to refer to both the resources existing within a State and those available from the international community through international cooperation and assistance. The Committee wishes to emphasize that in accordance with Articles 55 and 56 of the Charter of the United Nations, with well-established principles of international law, and with the provisions of the Covenant itself, international cooperation for development and thus for the realization of economic, social and cultural rights is an obligation of all States. It is particularly incumbent upon those States which are in a position to assist others in this regard. ${ }^{\mathrm{xxix}}$

In other words, although states have the primary obligation of ensuring that their subjects' human rights are secure, other states and international organizations that are well placed to do so must provide assistance if necessary.

One might question the above human rights framework on which everyone has a human right against extreme poverty that gives rise to high-priority duties (on humanity) to ameliorate extreme poverty. Specifically, one might wonder just how demanding the duty on humanity to ameliorate extreme poverty should be.

Our answer to this question is simple: humanity must ameliorate extreme poverty as much as possible without sacrificing something of comparable moral significance. ${ }^{\mathrm{xx}}$ Of course, one might then wonder what sorts of goals compare with ameliorating extreme poverty. Or, more generally, one might wonder what justifies us in adopting this human rights framework in the first 
place. However, such questions go beyond the scope of this paper. It simply assumes that the above moral framework is justifiable. This is not to say that adopting a human rights framework is uncontroversial, but rather that (provisionally) doing so can help to illuminate potential moral shortcomings in the case of debt-for-climate swaps. Before using this framework to assess the morality of debt-for-climate swaps, however, it is helpful to consider some problems associated with structurally similar international loans.

\section{INTERNATIONAL LOANS AND ECONOMIC CONDITIONALITY}

Loans are conditional. Creditors make loans on the condition that their debtors will pay them back, usually with interest. In international lending, however, economic conditionality has become more complex and restrictive. Developing countries seeking international loans whether from more affluent countries or international financial institutions like the World Bank or International Monetary Fund - must often agree to implement economic reforms designed to promote macroeconomic stability and growth. They may require countries to:

- $\quad$ Liberalize trade (say) by reducing tariff and non-tariff trade barriers.

- $\quad$ Liberalize financial markets (say) by allowing world markets to dictate exchange rates or devalue local currencies against hard currencies such as the dollar.

- $\quad$ Diminish the role of the state in guiding the economy (say) by privatizing major sectors of the economy, decreasing government bureaucracy, and reducing spending on such things as healthcare, education, and welfare. ${ }^{\mathrm{xxi}}$

In short, international loans have traditionally been conditional on liberalization, deregulation, and privatization. Although the conditions on international loans continue to evolve in order to address worries about their timing, content, and efficacy, most international creditors remain committed to advancing these kinds of reforms. ${ }^{\text {xxii }}$

Some international loans that have traditional economic conditions attached are morally questionable, if not impermissible. At least such loans are impermissible if they undermine the ability of debtor countries to protect the human rights of their people now or in the future. Given 
the moral framework set forth in §II, it is the duty of humanity to ensure that all people are able to live minimally decent lives. On this view, an international loan is permissible only if it protects the human rights of people whose lives are affected by it. So, if meeting the conditions on an international loan prevents a debtor country from protecting its people from extreme poverty, the loan is prima facie impermissible. International creditors - whether countries or international financial institutions - have a duty to ensure that the conditions they place on their loans preserve the ability of debtor countries to protect their people from extreme poverty. That is to say, international loans ought to be sustainable: as we will understand 'sustainability,' an international loan is sustainable only if the debtor country can protect its people from extreme poverty while servicing the conditions of the loan.

Although this way of construing sustainability might sound unorthodox, it is at least closely connected to the traditional understanding. To be sustainable, a practice must not compromise the fundamental interests or autonomy of individuals in present or future generations. Although questions about sustainability are most often asked in the context of environmental practices, they can just as well be asked in the context of economic practices. Finally, while this paper focuses on the human interests associated with sustainability, nothing we say here precludes the relevance of environmental interests to questions of sustainability.

Unfortunately, there appear to be real-world cases in which international loans with traditional economic conditions attached are unsustainable. In 1998, for instance, the World Bank and International Monetary Fund worked with the Bolivian government to privatize its public enterprises - including Bolivia's water company (SEMAPA) - as a condition of giving Bolivia a loan. ${ }^{\text {xxiii }}$ Subsequently, when the Bechtel Corporation took over the Bolivian water supply, many poor Bolivians saw their water bills triple or quadruple. In March 2000, Bolivians took to the streets in protest-demanding affordable water. Although Bechtel eventually relented, ${ }^{\text {xxiv }}$ it appears that Bolivia was unable to protect the human rights of its people while servicing the 
conditions on its loan. If so, the requirement on Bolivia to privatize its water supply was unsustainable and, therefore, morally questionable.

In another case, the International Monetary Fund required Ecuador to privatize its water and sewage system as a condition of giving Ecuador a loan. Although service improved in some respects, poor infrastructure led to an outbreak of hepatitis A, and poor Ecuadorians suffered as prices rose and subsidies were eliminated. As a result, some suggest that, in some parts of Ecuador, the poor were unable gain access to clean water and sanitation: $76 \%$ of the residents of Plan Piloto, for instance, characterized their water as 'turbulent and foul smelling'; 45\% said it was 'yellow or dark'; and 74\% said it smelled like feces. ${ }^{\mathrm{xxx}}$ It thus appears that Ecuador was unable to protect the human rights of its people while servicing the conditions on its loan. If so, the requirement on Ecuador to privatize its water and sewage system was unsustainable and, therefore, morally questionable.

Finally, in a third case, the International Monetary Fund pressured Niger to put a 19 percent value-added tax on goods - including foodstuffs - as a condition of giving Niger a loan. The tax was levied even though food costs had risen more than 75 percent in the previous five years, and even though Niger's nomadic herders' main source of income (livestock) had fallen 25 percent in value. ${ }^{x x v i}$ Although causation is notoriously hard to prove, there was famine in Niger that year, and the tax may well have been an aggravating factor. ${ }^{\text {xxxvii }}$ It thus appears that Niger was unable to protect the human rights of its people while servicing the conditions on its loan. If so, the requirement on Niger to impose a 19 percent value-added tax on goods - including foodstuffs - was unsustainable and, therefore, morally questionable.

\section{DEBT-FOR-CLIMATE SWAPS AND ENVIRONMENTAL CONDITIONALITY}

Now we turn to the permissibility of debt-for-climate swaps. International loans with traditional conditions attached are structurally similar to debt-for-climate swaps. Just as international loans require debtor countries to institute certain economic programs, debt-forclimate swaps require debtor countries to institute certain environmental programs. Both 
institutions exhibit the following structure: Creditor $C$ will do $X$ for debtor country $D$ if and only if $D$ institutes program $P$. The moral framework set out in $\S$ II places a sustainability condition on all such transactions: if a debtor country $D$ is unable to institute program $P$ while securing the human rights of its people (say, by protecting them from extreme poverty), then the transaction in question - whether an international loan or a debt-for-climate swap - is morally questionable, if not impermissible. We know from our discussion in §III that at least some international loans with traditional conditions attached are morally questionable for this reason, and, given the structural similarity between such loans and debt-for-climate swaps, we have reason to subject debt-for-climate swaps to a similar level of moral scrutiny.

Although debt-for-climate swaps are supposed to reduce a debtor country's international debt burden, this may not be enough for those offering such swaps to have discharged their moral duties to the people in that country. Whether those offering (or brokering) debt-for-climate swaps have discharged these duties depends on whether the swaps are sustainable-a matter for empirical inquiry. Such inquiry must examine whether a debtor country can fulfill the conditions on a debt-for-climate swap while maintaining the necessary economic growth, domestic infrastructure, and/or redistributive mechanisms sufficient for securing the human rights of its people. Suppose, for instance, that the World Wildlife Fund (WWF) brokers a debt-for-climate swap between the U.S. and Indonesia, in which the U.S. agrees to forgive US\$100 million of Indonesian debt so long as Indonesia agrees to institute a US\$20 million conservation program designed to protect its tropical rainforest. The permissibility of such a swap will depend on inter alia its sustainability: the US\$20 million conservation program must not prevent Indonesia from maintaining the economic growth, infrastructure, and redistributive mechanisms necessary to protect current and future generations of Indonesians from extreme poverty.

One might object that a debt-for-climate swap is permissible as long as it benefits a debtor country and its people. Rather than sustainability, one might say, perhaps the appropriate moral standard is that a swap just leave a country better able to secure the rights of its people. 
Indeed, one might insist that swaps are only problematic if they make a country less able to secure the rights of its people. ${ }^{\text {xxxviii }}$

While this may be so on some moral framework, it is not so on the human rights framework set out in §II. This is because a swap can lighten a country's debt burden, increase its ability to fulfill the rights of its people, and still prevent the country from completely fulfilling these rights. Suppose, for instance, the U.S. offers to reduce Indonesia's debt obligations if it agrees to create a nature reserve in a debt-for-climate swap. Even if the swap improves Indonesia's political power and the average welfare of Indonesians, for instance, creating the reserve could still make it more difficult (if not impossible) for Indonesia to help the very poor meet their basic needs. So, the permissibility of a debt-for-climate swap depends not simply on whether the debtor country and its people benefit from the swap. It also matters whether the country can protect its people from extreme poverty while fulfilling the environmental conditions placed on the swap.

Nonetheless, there may be cases in which a particular debt-for-nature swap is the best a creditor (or broker) can do to help a debtor country protect its people from extreme poverty. Perhaps the level of poverty, or the level of environmental degradation, is just that severe. Such cases present terrible choices, where creditors (or brokers) must choose between making an otherwise impermissible offer and doing what (say) has better consequences for the poor or the environment. If an unsustainable debt-for-nature swap happens to be the morally best option available to a creditor (or broker), then offering (or brokering) the swap may be the right thing to do in the circumstances. But this is a terrible choice even if it's easy to make and no one is blameworthy for having to make it.

By classifying the right choice as terrible, one expresses an abiding interest in avoiding circumstances where we are forced to make ourselves complicit - however blamelessly - in the perpetuation of extreme poverty and, other things being equal, the violation of human rights. ${ }^{\text {xxix }}$ The importance of this point cannot be overstated, since it is precisely by doing this that we can 
guard against failures of imagination which result in the unnecessary perpetuation of extreme poverty and human rights violations. Because the permissibility of offering (or brokering) an unsustainable debt-for-climate swap depends on the absence of better options, we must be sure to exhaust our imaginations before concluding that our best option is an unsustainable debt-forclimate swap. If we fail to exhaust our imaginations in the effort to find feasible alternatives to unsustainable debt-for-climate swaps, then we make ourselves not only complicit but culpable in the perpetuation of extreme poverty and violation of human rights. ${ }^{\mathrm{xl}}$ Indeed, this is the more general thrust of our argument: we must ensure that debt-for-climate swaps, which seem wonderful on the surface, do not provide creditors and brokers with an all-too-easy excuse for their conduct in a world that allows for the perpetuation of extreme poverty.

So far this paper has argued that debt-for-climate swaps are morally questionable when they are unsustainable, but there are likely other salient conditions on their permissibility-in addition to sustainability. We have thus far assumed that the debt being swapped for nature in debt-for-climate swaps comes from valid loans. But this need not be the case. The original loan could be odious. Odious loans are either (1) accepted by those without legitimate authority or (2) used for purposes that do not benefit the debtor country or its inhabitants. ${ }^{x l i}$ If, for instance, a dictator accepts a loan and embezzles the money, then that country's citizens should not be held to account. Other things being equal, these loans are invalid. So it seems that the permissibility of debt-for-climate swaps will be contingent on the validity of the original loans underlying the swaps. If those involved in offering (or brokering) a debt-for-climate swap know (or should have known) that the original loan is invalid - say, because it's odious or unsustainable -, then it may well be impermissible to offer (or broker) the swap.

More generally, creditors and brokers in debt-for-climate swaps must be acting in good faith. A colloquial example is helpful here. If one buys a Bose speaker system from Target, then one gains valid title to the speakers even if they turn out to have been stolen, since it is rarely (if ever) the case that goods sold at Target are stolen. If, however, one buys a Bose speaker system 
from a pawn shop, then the title may be invalid, since it is commonly the case that goods sold at pawn shops are stolen. As Leif Wenar explains:

In order for a purchaser to act in good faith, it must be reasonable for him to believe that he is dealing with a genuine vendor-one with neither void nor voidable title. It must be reasonable, that is, for the purchaser to believe either that the vendor is the owner of the good or that the owner has authorized the vendor while free from deception, duress, or undue influence. ${ }^{\text {xli }}$

Similarly, if those offering (or brokering) a debt-for-climate swap are acting in bad faith, they have no right to insist that the debtor country meet the environmental conditions placed on the swap.

There may also be other conditions on the permissibility of debt-for-climate swaps, though this paper will not focus upon them. Loans may, for instance, be impermissible because they are exploitative. ${ }^{\text {xlii }}$ Exploitative loans are offered by creditors who use their disproportionate bargaining power to coerce debtors into accepting conditions that would not otherwise be reasonable to accept. A debt-for-climate swap could be impermissible because it is based on an exploitative loan, or because the swap itself is exploitative. For the sake of brevity, however, what follows will focus only on the sustainability and good-faith conditions for permissibility.

Let us now turn to debt-for-climate (and, more generally, debt-for-nature) swaps in practice. Do real cases of debt-for-climate (or nature) swaps always (or generally) satisfy the conditions on permissibility set forth in §IV? Assuming the goodwill of all participating parties, this section will suggest that many may not. Debtor countries in debt-for-climate swaps (almost) invariably face unsustainable debt burdens. For this reason, it seems that those who offer (or broker) debt-for-climate swaps may be acting in bad faith-especially, since there is often little reason to think that the swaps will be sustainable.

Many poor countries are highly indebted with debt-to-export ratios of over 200 percent. ${ }^{\text {xliv }}$ Often poor countries' debt servicing obligations exceed all sources of government 
revenue. Econometric estimates give us reason to believe many of these countries' debts are unsustainable as on our definition as well as many others. The international financial institutions, for instance, suggest that many countries are unable to service their obligations even when they cut services to the poor. ${ }^{\mathrm{xlv}}$

A recent Jubilee report provides further evidence that massive debt is likely to prevent very poor countries from securing the human rights of their people. This report created a model for Malawi, Mozambique, Tanzania, and Uganda on which these countries cannot continue to service their projected debt burdens while meeting the Millennium Development Goal (MDG) of cutting extreme poverty in half by $2015 .{ }^{\text {xlvi }}$ In the case of Malawi, for instance, the report projects that, by 2015, Malawi would 'have a debt burden of at least $276 \%$ of GDP'xlvii even if Malawi tried to meet the MDG by excluding its existing debt and securing new loans. The report concludes that 'if Malawi financed the MDG cost gap through such borrowing, it would be completely unsustainable. ${ }^{\text {xlviii }}$ It is hard to see how countries that have to spend all of their money servicing massive debts will be able to protect their citizens' human rights from one generation to the next. If they are not able to do so, then, as discussed in §III above, the international loans that originally created the unsustainable debts are morally questionable, if not impermissible, and so, by extension, are any debt-for-climate swaps that serve to perpetuate such unsustainable debts in the form of environmental conditionality.

One might object that the evidence does not show that swaps are undermining human rights in any respect. Without the swaps poor countries and their people would be worse off. The swaps, instead, improve countries' ability to fulfill their subjects' human rights.

If one agrees, however, that traditional economic conditionality undermines human rights, one should agree that debt-for-climate swaps do so. For, the structure of debt-for-climate swaps is the same as the structure of traditional economic conditionality: Creditor $\mathrm{C}$ will do $\mathrm{X}$ for debtor country $\mathrm{D}$ if and only if $\mathrm{D}$ institutes program $\mathrm{P}$. The moral framework set out in §II places a sustainability condition on all such transactions: if a debtor country D is unable to institute 
program $\mathrm{P}$ while securing the human rights of its people (say, by protecting them from extreme poverty), then the transaction in question - whether an international loan or a debt-for-climate swap - is morally questionable, if not impermissible. It does not matter if, without $\mathrm{P}$, some other requirement $\mathrm{R}$ (e.g., the original conditions on a loan) were in place that would also undermine a country's ability to fulfill even the same people's human rights. The basic principle does not include an exception for cases where more people's rights are fulfilled or fewer undermined with $\mathrm{P}$ in place.

In light of these reflections, there is reason to worry that some debt-for-climate (or nature) swaps are impermissible. Some highly-indebted poor countries (HIPC) -- including Bolivia, Honduras, and Nicaragua -- have already received debt-for-climate (or other debt-fornature) swaps. ${ }^{\text {xlix }}$ At least, one should be just as inclined to question the permissibility of debt-forclimate swaps as one is to question the permissibility of the international loans on which they are based.

Furthermore, many of the debts developing countries bear were taken on by corrupt and treacherous rulers who did not use the loans to benefit their country or their people. Nor did the countries or institutions making these loans have good reason to think that these rulers would use the loans to aid the extremely poor. Ostensibly, then, there are many odious debts. For instance, much of the Philippines' debt acquired under Marcos, or Indonesia's debt acquired under Suharto, is odious. ${ }^{1}$ And yet, creditors have offered both the Philippines and Indonesia debt-forclimate (and nature) swaps. ${ }^{\text {li }}$ While more evidence is needed to establish that the creditors (or brokers) in these swaps were acting in bad faith, it seems that suspicion is warranted.

As noted above, there may be cases in which the best option available to those offering (or brokering) debt-for-climate swaps is to offer (or broker) an unsustainable or bad faith swap. If that is the best they can do, then it may be better than doing nothing. But, again, this is a terrible choice, even if no one is blameworthy for having to make it. 


\section{OBJECTIONS}

\section{Are debt-for-climate swaps uniquely wrong?}

One might object that the paper has done nothing to show that anything is distinctively wrong (or questionable) about debt-for-climate swaps. After all, what are debt-for-climate swaps, but creative attempts by well-meaning people to address the problem of environmental degradation while simultaneously lessening the massive debt burdens of developing countries? Surely there is nothing wrong with this, and just as surely, one might argue, the paper has done nothing to locate the potential wrongness of debt-for-climate swaps in its analysis of the swaps themselves.

While this objection is correct in claiming that the paper does not account for the distinctive wrongness of debt-for-climate swaps, we believe this objection implies an absurd standard for evaluating the moral status of debt-for-climate swaps, or anything else for that matter. ${ }^{\text {lii }}$ The fact that debt-for-climate swaps might be impermissible for the same reason(s) that other kinds of acts are impermissible does not vitiate the claim that there is reason to worry that something is wrong with debt-for-climate swaps. If, for instance, one were to argue that factory farming is wrong because it violates the principle of utility, it would be no defense of factory farming to respond by saying that many things can violate the principle of utility. Similarly, if one were to argue that lying is wrong because it violates the Categorical Imperative, it would be no defense of lying to respond by saying that many things can violate the Categorical Imperative. We argue that debt-for-climate swaps are morally questionable because those offering (or brokering) the swap may thereby fail to fulfill their positive obligations to the poor, if not undermine these rights. It is no defense of debt-for-climate swaps to respond by saying that there are other ways people can fail to fulfill the obligations correlative to human rights. In short, different acts can be impermissible for the same reason. 


\section{Are we asking too much of debt-for-climate swaps?}

One might still object that we are asking too much of debt-for-climate swaps when we make their permissibility contingent on how they impact the poor. Extreme poverty exists for a variety of reasons that have little or nothing to do with debt-for-climate swaps themselves, including the economic actions and policies of corporations, affluent countries, international financial institutions, and vicious dictators. In this context, one might argue, it is a mistake to conclude that debt-for-climate swaps are morally questionable, if not impermissible, simply because they fail to make a non-ideal world ideal.

Again, we believe this objection misses the thrust of the paper's argument. Our point is that the permissibility of debt-for-climate swaps depends on how they impact individuals' basic human rights. We do not conclude, as the objection suggests, that the permissibility of debt-forclimate swaps depends on whether they provide a panacea to extreme poverty, much less all the world's ills. That said, we do suppose that the circumstances in which one offers (or brokers) a debt-for-climate swap are relevant to its permissibility, since how a debt-for-climate swap affects people's ability to secure the objects of their human rights will depend on background facts over which those who offer or broker the swap have no control. It makes sense to judge the permissibility of debt-for-climate swaps - or anything else for that matter - in accordance with their real-world effects, not in accordance with the effects they would have had were the world a much different place. Presumably, we are responsible for the actual (if foreseeable) consequences of our actions, not the counter-factual consequences of our actions. For instance, we cannot excuse ourselves for pushing somebody off the edge of a cliff simply by pointing out that (a) we were not responsible for him standing at the edge of a cliff, and that (b) our push would not have sent him over the cliff were he standing in the middle of a cornfield. Similarly, creditors and brokers of debt-for-climate swaps cannot excuse themselves from pushing people into extreme poverty simply by pointing out that (a) they were not responsible for such people being on the edge of extreme poverty, and that (b) the debt-for-climate swap would not have pushed people 
into extreme poverty were the economic actions and policies of affluent countries, corporations, international financial institutions, or vicious dictators different. A similar argument applies in cases where, given existing background conditions, debt-for-climate swaps merely prevent people from escaping extreme poverty.

Furthermore, the fact that the world might have to change in certain ways in order for certain debt-for-climate swaps to be permissible does not undermine the paper's argument. Rather, it expands the significance and import of the paper, since there likely are ways of changing national and international policies, rules, and institutions so that they protect human rights better than the status quo. Thomas Pogge has argued, for instance, that we should collect a global tax on the use of natural resources and use the dividends to ameliorate extreme poverty. ${ }^{\text {lii }}$ And one of us has argued elsewhere that there are ways of changing the rules of trade and aid that could greatly help the poor. ${ }^{\text {liv }}$ No matter the efficacy of any specific proposal, however, the paper's general conclusion still stands: the permissibility of debt-for-climate swaps depends (in part) on whether the international community exercises its collective imagination in the effort to eliminate extreme poverty.

Again, this is not to deny that there may well be cases in which an unsustainable or bad faith debt-for-climate swap is the best option available. But, as argued in $\S \mathrm{IV}$, we should make every effort to avoid having to make such terrible choices-even if circumstances ultimately dictate that no one is blameworthy for having to make them.

\section{What about the value of nature?}

One might object that protecting nature is just as important as, if not more important than, securing human rights. So, the objector might suggest, a moral framework based solely on human rights, which lacks an environmental ethic, is inadequate to morally evaluate debt-for-climate swaps. Some might argue, for instance, that there is an obligation to give equal consideration to animal interests, ${ }^{\text {lv }}$ to treat all teleological subjects of a life as members of our moral community, ${ }^{\text {lvi }}$ or to protect species, ecosystems, and the biosphere for their own sake. ${ }^{\text {lvii }}$ These people might 
claim that, even if debt-for-climate swaps undermine the ability of people to avoid extreme poverty, they are permissible so long as they succeed in protecting the environment. Indeed, if a debt-for-climate swap will help mitigate the effects of climate change, or save some species from extinction, then such a swap may well be obligatory. After all, many environmentalists have argued for similar conclusions. lviii $^{\text {in }}$

We believe, however, that this objection removes both extreme poverty and environmental degradation from their proper context. A concern for the poor and the environment are interconnected. Those who care about extreme poverty have a reason to care about environmental degradation and vice-versa. ${ }^{\text {lix }}$

First, the poor are extremely vulnerable to environmental problems like climate change. Natural disasters and famines have harmed or resulted in the deaths of billions of poor people over the course of the last decade. ${ }^{\mathrm{lx}}$ Hundreds of thousands of poor people die every year from infectious diseases like malaria. ${ }^{\text {lxi }}$ And environmental problems like climate change are likely to aggravate the harms to people that result from such natural causes. ${ }^{\text {Ixii }}$ Moreover, because people in extreme poverty are the most exposed to environmental degradation and the least able to adapt to changing environmental conditions, ${ }^{1 \text { xii }}$ they are likely to suffer most from the effects of environmental problems like climate change. ${ }^{\text {lxiv }}$ Thus, people who care about ameliorating extreme poverty on human rights grounds have a reason to care about mitigating environmental problems like climate change.

Second, the poor, collectively, contribute a surprising amount to environmental degradation by using scarce sinks (like forests) that absorb wastes such as (excess) carbon dioxide. ${ }^{\mathrm{lxv}}$ For instance, swidden (or slash and burn) agriculture - usually employed by poor farmers who want to plant crops or raise cattle on marginal lands - causes immense deforestation. Poor people, who lack access to electricity or gas, also burn lots of wood and coal to cook their meals and heat their homes. ${ }^{\text {lxvi }}$ Moreover, developing country emissions will rise as they start using more fossil fuel, and it is estimated that developing countries will emit more carbon dioxide 
than industrialized countries by about 2018. ${ }^{\text {lxvii }}$ People who care about mitigating environmental problems like climate change thus have a reason to care about ameliorating extreme poverty.

Because extreme poverty and environmental degradation are interconnected, conflict between the imperatives to protect human rights and the environment is by no means certain. An unsustainable debt-for-climate swap that exacerbates extreme poverty may likewise exacerbate environmental degradation. Consider, for instance, the debt-for-climate swap that created the Beni Biosphere Reserve in Bolivia. The Tsimane' Indians who live in the reserve increase foraging and forest clearing when they are otherwise unable to meet their basic needs. These activities have the potential to devastate the reserve and undermine the environmental aims of the swap. ${ }^{\text {lxviii }}$ Therefore, whether the Bolivian swap will mitigate, or exacerbate, environmental degradation depends on whether it will protect the ability of the Tsimane' Indians to meet their basic needs. So, while debt-for-climate swaps hold out the hope of providing win-win solutions to the problems of environmental degradation and extreme poverty, unsustainable debt-for-climate swaps may well fail on both counts. Of course, the possibility of an intractable conflict between the needs of nature and the needs of people remains, but, again, this is compatible with the claim that unsustainable and bad faith debt-for-climate swaps are morally questionable.

\section{CONCLUSION}

Debt-for-climate swaps appear to provide win-win solutions to the very large and horrific problems of environmental degradation and extreme poverty. We do not question the intentions of those who would offer (or broker) debt-for-climate swaps, and we believe that they may well have a role to play in the larger efforts to confront these problems. Nevertheless, this paper has argued that, appearances notwithstanding, debt-for-climate swaps are sometimes morally questionable, if not impermissible. Putting aside cases in which terrible choices must be made, debt-for-climate swaps, like international loans, are permissible only if they are sustainable and offered (or brokered) in good faith. Unfortunately, like many international loans, there is reason to worry that some real-world debt-for-climate (or nature) swaps have, in fact, been 
impermissible. In any case, the practical upshot of the paper is that creditors and brokers of debtfor-climate swaps must be vigilant to avoid offering (or brokering) unsustainable or bad faith swaps. Such vigilance requires that creditors and brokers of debt-for-climate swaps use their imaginations in order to avoid having to make terrible choices between mitigating environmental degradation and protecting people from extreme poverty. 
i The authors would like to thank Debra Satz, Henry Shue, Jovana Davidovic, Jennifer Welchman, Don Maier, and audiences at Stanford University at annual meeting of the International Society for Environmental Ethics and the International Association for Environmental Philosophy.

ii The moral conclusions we can draw from these facts are less clear. See, for instance: Author, Forthcoming a.

iii See, for example, IPCC 2007, 2007, pp. 26 - 32; Gardiner, 2004; Mayell, 2002.

iv 'Some 831 million human beings are undernourished, 1197 million lack access to safe water and 2747 million

lack access to standard sanitation... About 2000 million lack access to essential drugs... Some 1000 million have no adequate shelter and 2000 million lack electricity... Some 876 million adults are illiterate... and 250 million children between 5 and 14 do wage work outside their household — often under harsh or cruel conditions: as soldiers, prostitutes, or domestic servants, or in agriculture, construction, textile or carpet production.' Pogge, 2006.

v UNCF, 2005; WHO, 2004.

vi See WWF, 2008.

vii See McCarthy, 2002.

viii See, for example, Gore, 2006.

ix Ibid.

x Ibid.

xi Ibid. 
xii Conservation International, 2009.

xiii ENS, 2002.

xiv See, for example, Jubilee, 2000; World Bank, 2008.

xv See, for example, ENS, 2002.

xvi SOP Newswire, 2006; TNC, April 2010.

xvii SOP Newswire, 2006.

xviii EPA, 2010; Herring and Kannenberg, April 2010.

xix Samath, 2008; ecoEconomics, April 2010.

xx See, for example, Nickel, 2007; Pogge, 2002; Buchanan, 2007.

xxi Nickel 1993 and 1995; Pogge, 2002; Buchanan, 2007: Gewirth, 1996.

xxii For preliminary defense of this conception of rights see Author, Forthcoming c.

xxiii At least, that is, people have a right against standard threats to their ability to live a minimally good life, and

to have standard protections of this ability.

xxiv Nickel, 2005, p. 396. For an expanded discussion of this, see Nickel 1993 and 1995.

xxv See Pogge, 2002; Buchanan, 2007.

xxvi See Pogge, 2002; Buchanan, 2007.

xxvii People and non-state institutions also have secondary obligations to assist in protecting human rights. As

citizens, for instance, we have obligations to vote or campaign for appropriate protections. 
Xxviii '[O]ver time the general comment has become a distinct juridical instrument, enabling the [Human Rights

Committee] to announce its interpretations of different provisions of the [ICCPR] in a form that bears some

resemblance to the advisory opinion practice of international tribunals. These general comments or 'advisory

opinions' are relied upon by the Committee in evaluating the compliance of states with their obligations under

the Covenant, be it in examining State reports or 'adjudicating' individual communications under the Optional

Protocol... General comments consequently have gradually become important instruments in the lawmaking

process of the Committee, independent of the reporting system.' Steiner and Alston, 2000.

xxix From: CESCR, 1990. Furthermore, the charter of the UN also expresses this understanding of the obligation

to ameliorate poverty along with secure other conditions for stability and well being. Consider articles 55 and 56

of Chapter IX of this charter, for instance. Article 55 says: 'With a view to the creation of conditions of stability

and well-being which are necessary for peaceful and friendly relations among nations based on respect for the

principle of equal rights and self-determination of peoples, the United Nations shall promote: a. higher standards

of living, full employment, and conditions of economic and social progress and development; b. solutions of

international economic, social, health, and related problems; and international cultural and educational co-

operation; and c. universal respect for, and observance of, human rights and fundamental freedoms for all

without distinction as to race, sex, language, or religion.' Article 56 says: 'All Members pledge themselves to

take joint and separate action in co-operation with the Organization for the achievement of the purposes set forth

in Article 55.' U.N., 1945. 
xxx See Singer's 1972 discussion of comparable moral significance. For us, as for Singer, the idea is merely

formal and contains no assumptions about what the content of morality requires. Admittedly, then, it may turn

out that human rights considerations against debt-for-nature swaps are outweighed by countervailing

considerations in their favor (e.g., the value of nature to be preserved in the swap).

xxxi See, for example, Bello, 1996; Sachs, 2005.

xxxii Looking at the guidebook for countries it seems privatization, liberalization and freer trade are encouraged:

(The World Bank, 2010). Attending to the content of the particular programs implemented in developing

countries after the supposed end of structural adjustment also allows us to see how similar the new requirements

are to the old requirements (IMF, 2003).

xxxiii IMF and World Bank, 1998.

xxxiv Bechtel took Bolivia to court but eventually settled for a nominal amount due to international pressure.

xxxv Joiner, 2007, p. 15.

xxxvi Engler, 2005.

xxxvii Amanthis, 2005.

xxxviii The authors would like to thank Henry Shue for pressing them on this point.

xxxix Indeed, we may even be able to rationally regret having to make a terrible choice that prevents us from

realizing something we value such as the protection of human rights. We do not suggest that the above cases 
present tragic dilemmas only because we do not want to enter into the debate about whether truly tragic

dilemmas are possible here. See Stocker 1990, however, for more on rational regret in terrible circumstances.

xl Author, 2009b.

xli Gosseries, 2008.

xlii Wenar, 2007, p. 25.

xliii As with debt-for-nature swaps the best one may be able to do in some circumstances is offer an exploitative loan or give money to a bad leader, but it is terrible if that is the best one can do. We would like to thanks Henry Shue for encouraging us to make this qualification explicit.

xliv IMF and World Bank, 1990; IMF 2010.

xlv Gunter, 2003.

xlvi Kapoor, 2004

xlvii Kapoor, 2004, p. 15

xlviii Kapoor 2004, p. 15

xlix See WWF, 2003; IMF 2010.

1 See Dancel, 2002; Gee, 2000.

li See ENS, 2002; Khalik, 2007; Photius, 2008a and 2008b.

lii This is not to say that there is nothing to be gained by doing analyses of this sort. It may well be that there are sometimes aspects of certain acts that make them distinctively wrong. For a wonderful analysis of this kind, in 
the case of terrorism, see McPherson 2007. In any case, moral evaluations of this kind seem to be in the minority

of evaluations done by moral philosophers, where, as in this paper, a general moral framework is applied to a

specific kind of act.

liii Pogge, 2002.

liv Author, Forthcoming b; Author, 2009a; Author, 2008.

lv See, for example, Singer, 1993.

lvi See, for example, Taylor, 1986.

lvii See, for example, Naess, 2005.

lviii See, for example, Rolston, 2002.

lix See Jamieson, 2005.

lx U.N., 2004.

1xi CDC, 2004.

lxii IPCC 2007, 2007, p. 26.

lxiii U.N., 2004.

lxiv The introduction to the Delhi Ministerial Declaration on Climate Change and Sustainable Development articulates this worry about Least Developed Countries and Small Island Developing State. See UNFC, 2002.

lxv See World Bank, 2006.

lxvi See Schmidtz 2002a and 2002b. 
lxvii EIA, 2004.

lxviii See Carmen, 1995. 


\section{REFERENCES}

Amanthis, Judith. 2005, September 1. 'Niger: The IMF and World Bank's Invisible War on Africans,' Global Policy Forum. Available online at: <http://www. globalpolicy.org/socecon/bwi-wto/imf/2005/0901invisible.htm>.

Author. Forthcoming a. With-held.

Author. Forthcoming b. With-held.

Author. Forthcoming c. With-held.

Author. 2009a. With-held.

Author. 2009b. With-held.

Author. 2008. With-held.

Bello, Walden. 1996. 'Structural Adjustment Programs: "Success; for Whom?”,

The Case Against the Global Economy and for a Turn Toward the Local. Sierra Club Books: San Francisco.

Buchanan, Allen. 2007. Justice, Legitimacy, and Self-Determination: Moral Foundations for International Law. Oxford University Press: Oxford.

Carmen, Miranda L. 1995. 'The Beni Biosphere Reserve.' South-South Cooperation Programme on Environmentally Sound Socio-Economic Development in the Humid Tropics: Working Papers, No. 9. Available online at: http://unesdoc. unesco.org/images/0011/001123/112392Eo.pdf.

Center for Disease Control and Prevention (CDC). 2004. 'The Impact of Malaria, a Leading Cause of Death.' Department of Health and Human Services: Georgia. Available online at: <http://www.cdc.gov/malaria/impact/index.htm >.

Committee on Economic, Social and Cultural Rights (CESCR). 1990. General Comment 3, The nature of States parties' obligations (Fifth session, 1990), U.N. Doc. E/1991/23, annex III at 86 (1991), reprinted in Compilation of General Comments and General 
Recommendations Adopted by Human Rights Treaty Bodies, U.N. Doc. HRI/GEN/1/Rev.6 at 14 (2003).

Conservation International. June 30, 2009. 'US to Forgive \$30m Debt to Protect Sumatra's Forests.' Available online at: <http://www.conservation.org/sites/ gcf/news/Pages/debtfornaturesumatra.aspx $>$.

Dancel, Raul. 2002, September 21. 'Foreign debt: the price of greed?' Odious Debts: News articles - Philippines: Odious Debts. Available online at: <http://www. odiousdebts.org/odiousdebts/index.cfm?DSP $=$ content $\&$ Content ID=5648>. ecoEconomics, April 2010. 'Swapping non-performing debts for "Real Carbon Credits".'

Available online at: <http://www.ecoeconomics.org/ee/swap.html\#a02>.

Energy Information Administration (EIA). 2004. 'What Are Greenhouse Gases?'

Greenhouse Gasses Programs. Energy Information Administration. Department of Energy: Washington D.C. Available online at: <http://www.eia .doe.gov/oiaf/1605/ggccebro/ chapter1.html>.

Engler, Yves. 2005, August 13. 'Market Famines.' Znet. Available online at: <http://www.zmag.org/content/showarticle.cfm?ItemID=8494>.

ENS. 2002, June 23. 'World's Largest Eagle to Benefit from Debt Swap,' Environment News Service. Available online at: <http://www.ens-news wire.com/ens/sep2002/2002-09-23-03.asp>.

EPA, 2010. Available online at: <http://www.epa.gov/sequestration/rates.html>.

Gardiner, Stephen M. 2004. 'Ethics and Global Climate Change,' Ethics, vol. 114, pp. 555-600.

Gee, Marcus. 2000, August 4. 'Suharto charged with corruption,' Odious Debts: Corruption. Available online at: <http://www.odiousdebts.org/odiousdebts/ index.cfm?DSP $=$ content $\&$ ContentID=5005>. 
Gore, Al. 2006. Earth in the Balance. Rodale Books: New York.

Gosseries, Axel. 2008. 'Should They Honor the Promises of Their Parents' Leaders?' in Dealing with Developing Country Debt. eds. Christian Barry, Barry Herman, and Lydia Tomitova. Blackwell: Oxford.

Gewirth, Alan. 1996. The Community of Rights. University of Chicago Press: Chicago.

Gunter, Bernhard G. 2003, February 26. 'Achieving Lont-Term Debt Sustainability in All Heavily Indebted Poor Countries (HIPCs).' Available online at: <http:// www.g24.org/guntetgm.pdf>.

Herring and Kannenberg, April 2010. 'The Mystery of Missing Carbon' Available online at: <http://earth observatory.nasa.gov/Features/BOREASCarbon/>.

International Monetary Fund (IMF). 2010. 'Debt Relief Under the Heavily Indebted Poor Countries (HIPC) Initiative.' Factsheet. Available at: <http://www.imf.org/external/np/exr/facts/hipc.htm>. . 2010. 'Tanzania Poverty Reduction Strategy Paper Progress Report.' IMF Country Report No . 03/96. Available at: $<$ http://siteresources.worldbank.org/INTPRS1/Resources/Country-Papers-andJSAs/cr0396.pdf (e.g., p. 33)>.

International Monetary Fund and World Bank. 1999. Heavily Indebted Poor Countries (HIPC) Initiative. Available online at: <http://www.imf.org/external/np/hipc/modify/hipc.htm>. . March 1999. Zambia: Enhanced Structural Adjustment Facility

Policy Framework Paper, 1999-2001. Available online at: <http://www.imf. org/external/NP/PFP/1999/Zambia/\#IIIC>. 1998. ESAF Policy Framework Paper. Available online at: <www.imf.org/ external/np/pfp/bolivia/index.htm $>$. Cited here $<$ http://www. citizen.org/documents /Bolivia_(PDF).PDF)>. 
IPCC. 2007. Climate Change 2007: Synthesis Report. Available online at: <http:// www.ipcc.ch/pdf/assessment-report/ar4/syr/ar4_syr.pdf>.

Jamieson, Dale. 2005. 'Adaptation, Mitigation, and Justice,' in Perspectives on Climate Change: Science, Economics, Politics, Ethics. eds. Walter Sinnott-Armstrong and Richard Howarth. Advances in the Economics of Environmental Resources, vol. 5. Elsevier: New York.

Joiner, Emily. 2007. 'Murky Waters: A Look at the Perpetual Puzzle of Water and Sanitation Services in Guayaquil, Ecuador.' ILASSA Student Conference Proceedings Archive. Available online at: <http://lanic.utexas.edu/ project /etext/ llilas/ilassa/2007/ joiner.pdf>.

Jubilee. 2008, December 31. 'Truth about Debt.' Available online at: <http://www. jubileeusa.org/truth-about-debt>.

Kapoor, Sony. 2004. 'Resource Rich BWIs, 100\% Debt Cancellation and the MDGs,' Jubilee Research and New Economics Foundation. Available online at: <http: //www.jubileeresearch.org/news/mdgpaper.pdf>.

Khalik, Abdul. 2007, July 3. 'U.S. Offers Indonesia Debt-for-Nature Swap,' The Jakarta Post. Available online at: <http://www.indonesiaottawa.org/ informati on/details.php?type=news_copy\&id=4307>.

Mayell, Hillary. 2002, January 30. 'Climate Studies Point to More Floods in This Century,' National Geographic News. Available at: <http://news.national geographic.com/news/2002/01/0130_020130_greatfloods.html>.

McCarthy, Terry. 2002, August 18. 'Let Them Run Wild,' Time. Available online at: <http://www.time.com/time/2002/greencentury/enwilderness.html>.

McPherson, Lionel K. April 2007. 'Is Terrorism Distinctively Wrong?' in Ethics Vol. 117 , pp. 524-546. 
Naess, Arne 2005. The Selected Works of Arne Naess. Harold Glasser ed. Vols. 1-10. Spring: New York.

Nickel, James W. 2007. Making Sense of Human Rights. Blackwell Publishing: Oxford. 2005. 'Poverty and Human Rights,' in The Philosophical Quarterly Vol. 55

No. 220.

1995. 'A Human Rights Approach to World Hunger,' in World

Hunger and Morality, $2^{\text {nd }}$ edn. Prentice Hall: Englewood Cliffs, pp. 171-185. Cited in Nickel 2005. 1993. 'How Human Rights Generate Duties to Protect and Provide,' in Human Rights Quarterly, 14, pp. 77-86. Cited in Nickel 2005.

Photius. 2008a, December 31. 'Philippines External Debt.' Available online at: $<$ http://www.photius.com/countries/philippines/geography/philippines_ geography_external_debt.html>. . 2008b, December 31. 'Indonesia: Foreign Aid, Trade, and Payments.' Available online at: <http://www.photius.com/countries/indonesia/economy/in donesia _economy_foreign_aid_trade_ 15.html >.

Pogge, Thomas. 2006. 'Severe Poverty as a Human Rights Violation,' in Freedom from Poverty as a Human Right: Who Owes What to the Very Poor? ed. Thomas Pogge. Oxford University Press: Oxford. . 2002. World Poverty and Human Rights: Cosmopolitan Responsibilities and Reforms. Polity Press: Cambridge.

Reed, David et. al. 1996. Structural Adjustment, The Environment and Sustainable Development. David Reed Ed. World Wildlife Fund. Earthscan Publications Ltd.: London. 
Rolston III, Holmes. 2002. 'Feeding People Versus Saving Nature,' in Environmental Ethics What Really Matters, What Really Works. David Schmidtz and Elizabeth Willott eds. Oxford University Press: New York.

Sachs, Jeffrey D. 2005. The End of Poverty: Economic Possibilities for Our Time. Penguin Books: New York.

Samath, Feizal 2008. 'SRI LANKA: Trading Debts Against Carbon Credits?' Available online at: $\langle$ http://ipsnews.net/news.asp?idnews=44150 $>$.

Schmidtz, David. 2002a. 'When Preservationism Doesn't Preserve.' Environmental Ethics: What Really Matters, What Really Works. David Schmidtz and Elizabeth Willott eds. Oxford University Press: New York. . 2002b. 'Natural Enemies: An Anatomy of Environmental Conflict.' Environmental Ethics: What Really Matters, What Really Works. eds. David Schmidtz and Elizabeth Willott. Oxford University Press: New York.

Singer, Peter. 1993. Practical Ethics. Cambridge University Press: Cambridge. 1972. 'Famine, Affluence and Morality.' in Philosophy and Public Affairs, Vol. 1, no. 1, pp. 229-243.

SOP Newswire, 2006. 'US Nature-for-debt swap called win-win deal for developing world.' Available online at <http://thesop.org/story/art/2006/10/06/us- nature- for-debt-swapcalled-win-win-deal-for-developing-world.php>.

Steiner, H. and Alston, P. 2000. International Human Rights in Context (2nd ed.), Oxford University Press: Oxford. p. 732.

Stiglitz, Joseph. 2003. Globalization and Its Discontents. W.W. Norton \& Co.: New York.

Stocker, Michael. 1990. Plural and Conflicting Values. Clarendon Press: Oxford. Taylor, Paul. 1986. Respect for Nature. Princeton University Press: New Jersey. 
TNC, April 2010. 'Costa Rica: A Landmark Deal for Lasting Conservation.' Available online at: <http://www.nature.org/wherewework/centralamerica/costarica/ misc/art22576.html)>.

United Nations (U.N.). 2004. 'Disaster Reduction and the Human Cost of Disaster.' United Nations Office for the Coordination of Humanitarian Affairs. United Nations: Geneva. Available online at: <http://web.worldbank.org/WBSITE/EXT ERNAL/NEWS/0,,contentMDK:20169861 menuPK:34457 pagePK:34370 piPK:34424 $\sim$ theSitePK:4607,00.html>.

United Nations (U.N.). 1945. 'Article 56.' Available at: <http://www.un.org/aboutun/charter/>.

UNCF. 2005. Millennium Development Goals: Combat AIDS/HIV, Malaria, and other Diseases. United Nations Children's Fund: New York.

United Nations Framework Convention on Climate Change (UNFCC). 2002. 'The Delhi Ministerial Declaration on Climate Change and Sustainable Development.' Eighth Conference of the Parties of the Framework Convention on Climate Change. United Nations: Geneva. Available online at: <http://unfccc.int/cop8/latest/1_cp16rev1.pdf\#search=\%22delhi\%20declaration\%20\%20c limate $\% 22>$.

The World Bank. 2010. 'PRSP Sourcebook: Chapter and Annexes.' Available at: <http://web.worldbank.org/WBSITE/EXTERNAL/TOPICS/EXTPOVERTY/EXTPRS/0, ,contentMDK:22404376 pagePK:210058 piPK:210062 theSitePK:384201 isCURL:Y, 00.html>.

World Bank. 2008, September. 'Debt Relief: at a glance.' Available online at: <http:// web.worldbank.org/WBSITE/EXTERNAL/NEWS/0,,contentMDK:20040942 menuPK: 34480 pagePK:34370 theSitePK:4607,00.html>. 2006. 'Natural Disasters: Counting the Cost.' World Bank: Washington 
D.C. Available online at: <http://www.irinnews.org/webspecials/DR/default. asp>.

World Health Organization (WHO). 2004. The World Health Report 2004. WHO: Geneva. Available at: <www.who.int/whr/2004>. Annex Table 2

World Wildlife Fund (WWF). 2008. 'Conservation Finance: Debt-for-Nature Swaps.'

Available online at: <http://www.worldwildlife.org/what/howwedoit/ conservationfinance/debtfornatureswaps.html>.

World Wildlife Fund (WWF). 2003. 'Bilateral Debt-For-Environment Swaps by Creditor.' Center for Conservation Finance. Available at: <http://www.cbld.int/doc/external/wwf/wwfbilateral-swaps-en.pdf>. 